\title{
A Simultaneous Equation Analysis Of The Relationship Between Foreign Direct Investment, Public Expenditure And Economic Growth In Nigeria
}

\author{
Ovenseri-Ogbom, O. Friday \\ Umoru, David, PhD \\ Department of Economics, Banking \& Finance, \\ Benson Idahosa University, Benin City, Nigeria
}

doi: 10.19044/esj.2016.v12n4p483 URL:http://dx.doi.org/10.19044/esj.2016.v12n4p483

\begin{abstract}
The objective of the paper is to empirically examine the effect of FDI and public expenditure on the Nigerian economy. The simultaneous equation estimation was carried out in the study. From the elasticity-multiplier coefficient table, it became obvious that infrastructure measured by power generation is highly germane in stimulating economic growth and foreign direct investment. The study thus recommends the need for significant infrastructure such as power supply.
\end{abstract}

Keywords: Foreign Direct Investment (FDI), Public Spending, Economic Growth

\section{BACKGROUND}

Foreign direct investment (FDI) has been a subject of interest for economists since the post-second World War paring when European countries and Japan needed capital from the US to finance reconstruction following the damage caused by the war. Foreign direct investment has witnessed steal growth across various countries of the World. The central focus of FDI in the $21^{\text {st }}$ century is the emerging economies of Asia, Latin America and Africa. There has been a consistent increase in FDI into developing countries and these emerging economies. It has accounted for about a quarter of international capital outflows. FDI can have an impact on many aspects of a host country economy such as output, the balance of payments, and market structure (Vu Le and Suruga, 2005). However, it is believed that bridging the gap in technology between the countries is the main effect of FDI, which in turn improves the productivity and growth of the FDI bearing country (Moosa, 2002). The inflow of FDI has corresponding positive effect on the overall growth of the economy. In 
Nigeria since the advent of democratic rule in 1999, inflow of FDI has been on the increase, reports has it that Nigeria is the highest recipient of FDI in Sub-Sahara Africa.

Public expenditure is an important fiscal policy instrument for government to control the economy. Economists have been well aware of its two-side effects in promoting economic development and growth of the economy. On the other hand, public investment is a factor contributing to capital accumulation and capital formation (Baro, 1990). Public expenditures are also used to fill up the gap that are left untouched in market-propelled economy such as public utilities, health care, social security, critical infrastructure among others. On the other hand, however, tax, which is the entire financial source for public expenditures, does directly reduce the benefits of tax payers. As human capital pays the key role in promoting economic growth, a lower benefit of citizens is associated with a lower economic growth rate. Considering the economy as a whole, the question of how to judiciously appropriate public fund has been a difficult task.

There is a strong nexus between FDI, public expenditure and economic growth. On theoretical grounds, the major controversy has been on whether or not the public sector activities increase the long run steady state growth rate of an economic (Kweka and Morrisey, 1999). Another theoretical stand point also hinged on the fact that foreign direct investment (FDI) has the capacity to trigger off economic growth in a given economy. Previous empirical studies have found little or no consensus on the impact of public expenditure and foreign direct investment on economic growth (Gupta etal, 2002). According to Makki and Somwaru, (20020, earlier empirical studies though confirmed a positive effect of FDI on the overall growth of an economy. However, the degree of such impact depends on the absorptive capacity of the host country, which consists of the level of human capital infrastructure, financial and institutional development, and trade policies. Therefore, this study attempts to examine the relationship between foreign direct investment, public expenditure growth and economic performance in Nigeria. The study is structured into five sections. The next reviews the literature on the subject matter. The third section discusses theoretical framework, methodology and the data. Section four analyzes the regression results. The fifth section concludes the study.

\section{REVIEW OF LITERATURE Theoretical Literature}

From the traditional macroeconomic theory, it has been asserted that various types of public expenditure whether recurrent or capital in structure and outlook positively influences economic growth (Grossman, 1983). According to Girma (2003), economic growth is a manifestation of the 
combine activity of aggregate government expenditure and foreign direct investment (FDI) in his view, the combine forces of public expenditure and FDI speedily stimulate economic growth especially in growing and developing economy. High levels of government consumption are likely to increase employment, profitability and investment, both foreign and domestic via the Fiscal Policy Transmission Mechanism (FPTM) and the multiplier effects on aggregate demand, which eventually translate into economic growth. Thus, public expenditure increases the level of aggregate demand, leading to increased output depending on the size and effectiveness or soundness of expenditure multipliers. The opposite view opines that government consumption crowds out private investment (crowding out effect), dampens economic stimulus in the short run and reduces capital accumulation in the long run. Strictly speaking, crowding-out results from a fiscal debit and the associated effect from on interest rates but diverse economic impacts may be due to government spending in general (Diamond, 1989).

As one of the government's instruments together with taxation and welfare policy, public expenditure has been seen as the most potent economic agent in all modern societies (Arrow and Kurz, 1980). According to Asohauer, (1989); Barro, (1991); Earterly and Rebelo, (1993); Granmlich, (1994); Gupta etal, (2002); and Turnovsky, (2004); there is a negative relationship between economic and government consumption while there is a significant positive relationship between economic growth and aggregate government spending. The finding have not smooth dialing. In contrast to the above claim, many other is through various studies discovered a negative linkage between economic growth are public spending while same with nonrobust relationship between these two variables (Landau, 1986; Grier and Tullock, 1987; Devarajan etal, 1996; and Folster and Henrekson, 2001).

Studies predicated on endogenous growth models distinguish between distortionary or non-distortionary taxation and between productive or unproductive expenditures (Kneller etal, 1998). Barrow and Sala-i-Martin (1992) classified public expenditure as unproductive if they included as arguments in private production functions, and unproductive if they are not. This implies that productive expenditures have a direct effect upon the rate of economic growth but unproductive expenditure have indirect or no effect. The issue of which expenditure items should be categorized as productive or unproductive is dabatable, as is the appropriate identification non-distortion as against distortionary taxes.

According to Baro (1990), almost every study revealed that the relationship between public expenditure and economic growth is assumed implicit and that all government investment spending is productive. The literature of FDI study is not much engrossed in controversy as economists 
believe that FDI has a positive impact on the technology upgrading progress of the recipient country (Blomstron, 1992); Boreniztein etal, 1998; and Moosa, 2002) and it economic growth eventually. This impact can be found via many channels but mainly by increasing the degree of competition in host-country markets, incorporating now inputs and foreign technologies in the production function of the host country; and augment the level of knowledge in the host country. According to Vu Le and Suruga (2005), the impact of technological transfer to the host country as well as growth in the capital base of quoted companies through the activities of portfolio investment or foreign private investment have resulted in a quantum leap in the rate of growth in most developing economies of the World. Therefore public expenditure and FDI will necessarily have a "double-barrel effect" on economic growth.

The volume and type of FDI inflows as well as the degree of its impact on economic growth are argued to depend on the absorptive capacity of the host country. The main reason is because domestic firm need a certain absorptive capacity of the host country. The main reason is because domestic firm need a certain absorptive capacity before they can benefit from new technologies brought by foreign firms (Girma, 2003). At the macro level, the analysis of the absorptive capacity is done by examining the recipient economy's trade regime, legislation, political stability, economic strengthen such absorptive capacity, human resources, balance of payment constraints and the size of the domestic market for the goods produced through FDI (Balasubramanyam etal, 1990; Borensstein etal, 1998; de Mello, 1990 and Durham, 2004).

\section{Previous Empirical Studies}

Using a panel data from 22 OECD countries and using the generalized least square (GLS) estimation technique, Kneller etal; (1998) found out that productive expenditure enhances and stimulates economic growth, while non-productive spending has no positive impact on the level of economic growth among the countries under consideration. Landau (1983; and 1986) also used panel data form 27 less developed countries discovered that increasing government spending crowds out domestic and foreign direct crowds out domestic and foreign direct investment;. He concluded that government consumption expenditure has a negative impact on economic growth. Kormandi and Meguire (1985), observed from a panel data of 47 countries that government spending does not have significant effect economic growth but foreign direct investment (FDI) does.

According to Barro (1991), applying OLS estimation method for 98 countries and using a cross-sectional data, the government consumption has a negative but significant effect on economic growth. Hsieh and Lai (1994) 
applied Vector Autoregressive (VAR) method among G-7 countries the time series data revealed that no uniform causality between dependent and explanatory variables. He discovered that government spending marginally effects economic growth. Lin (1994) applied OLS two-stage least square (2SLS) and three-stage least square (3SLS) in estimating a panel data of 62 countries between 1960 and 1985, he found out that non-productive spending is insignificant to the level of growth in Advance Economies while government spending has positive impact on less developed countries (LDCs). Applying the panel data for 14 developed economies and using 5year Moving Average - OLS estimation technique, Devarajan and Vinaya (1993) observed that government spending on Health, transport and other critical infrastructure like communication has significant positive effect on economic growth while public expenditure on defence and education negatively impact on economic growth. They also discovered that FDI significantly has positive impact on economic growth.

\section{THE THEORY OF PUBLIC EXPENDITURE}

The theory of public expenditure may be discussed in the context of the range of public expenditure and/or in terms of the division of a given amount of public expenditure into different items. The former of the two parts may also be conceived in terms of allocation of the economy's resources between providing public goods on the one hand and private goods on the other.

Today, we have many diverse areas to which the theory of public expenditure has extended itself. The theory for example, has tried to address itself to the question of what public expenditure wants to achieve for the members of the society. In technical terms, it would mean specifying the objective function of a public expenditure project. With the recognition of the inability of the market mechanism to bridge the gap between private and social costs on the one hand and private and social benefits on the other, the theory of public expenditure is confronted with a lot difficulty. It should be note that the greater the imperfections of the market mechanism with reference to the chosen objectives of society, the greater would be the need for the authorities to expand their activities.

Under public expenditure theory, one problem seems outstanding. That is, the issue of devising a mechanism, which could generate proper, signals regarding the two preferences of the society. Moreover, even if we are able to diverse a proof signaling system to ascertain the preferences of the society, the same may be inconclusive or contradictory. The range of state activities is widening and is no longer confined to the provisions of pure public good. Moreover, as is now recognized, the state activities are 
increasingly covering distributional, welfare, planning, growth and other areas.

Earlier, we advanced that the advocacy and acceptance of laissezfaire, which tended to limit governmental activities to defense, the maintenance of law and order and the expectation that the invisible hand will serve as the equilibrating mechanism through the operation of the price system would have stalled the growth in public expenditure if the reasoning had survived through time. However, the failure of the market mechanism to respond to the needs of the society is the starting point of the theory of public expenditure. Over time, government have been involved in solving the problems associated with planning economic growth and development, reducing regional disparities and economic injustice, ensure appropriate income redistribution and so on.There are two important and well known theories of increasing public expenditure. The first one is connected with Wagner and the other with Wiseman and Peacock.

\section{Wagner's Law of Public Expenditure}

Wagner (1883) was a German economist who based his law of Increasing State Activities on historical facts, primarily of Germany. According to Wagner, there are inherent tendencies for the activities of different layers of a government (such as central, state and local governments) to increase both intensively and extensively. There is a functional relationship between the growth of an economy and government activities with the result that the governmental sector grows faster than the economy. According to Kusi (1997), the conventional interpretation of Wagner's law implies a continuous relative expansion of public spending as a consequence of the development process. Wagner explained that as a society becomes industrialized, the set of social, commercial and legal relationship within it become more complex. Government would be called upon to play a more prominent role in setting up and running institutions to control this complexity. These regulatory and protective functions of the state would cause an enlargement in the size of the public budget. Wagner reasoned that many public output are income elastic so that as development progresses and per capita income increases, demand for them increases by larger percentage. As the public sector responds to the increasing demand for its good and services the budgetary outlays, which accompany them, increases, and consequently the relative size of public expenditure expands. Among several other theoretical propositions for the expansion of public expenditures in both developed and developing countries of the world, the Wiseman-Peacock thesis, which harped on the time pattern of public expenditure growth, clearly complements Wagner's discourse on the absolute magnitude of public expenditures. 


\section{Wiseman-Peacock Theory}

The second thesis dealing with the growth of public expenditure was put forth by Wiseman and Peacock (1979). The main thesis of authors is that public expenditure does not increase in a smooth and continuous manner, but in jerks or step like fashion. At times, some social or other disturbance takes place creating a need for increased public expenditure which the existing public revenue cannot meet. While earlier, due to an insufficient pressure for public expenditure, the revenue constraint was dominating and restraining an expansion in public expenditure, now under changed requirements such a restraint gives way. The public expenditure increases and makes the inadequacy of the present revenue quite clear to everyone. The movement from the older level of expenditure and taxation to anew and higher level is the displacement effect. The inadequacy of the revenue as compared with the required public expenditure creates an inspection effect.

\section{SIMULTANEOUS EQUATION MODEL}

Based on the above theory, the model is therefore tailored after Tsoukis and Miller (2003). The model includes the determining factors of GDP growth and FDI. Infrastructure development which is captured by generation is expected to reflect technological upgrading progress which is to determine FDI. It is assumed that the government attempts to maximize the $\mathrm{s}$ the following CES function:

$$
\begin{aligned}
& \stackrel{\mathrm{U}}{=} \int\left(\mathrm{C}^{1-0}-1\right) /(1-\Phi) \mathrm{P}^{-\mathrm{pt}} \mathrm{dt} \\
& 0
\end{aligned}
$$

The production function is assumed to have the following form: $\mathrm{Y}=\mathrm{AK}^{1-\Phi}\left(\mathrm{P} \alpha \mathrm{H}^{1-} \alpha\right)^{\Phi}, \mathrm{A}=/(\mathrm{F}) 0<\Phi, \alpha<1$

Where $\mathrm{C}$ is consumption expenditures, $\Phi$ is inter-temporal substation elasticity: $\Phi>0, P$ is constant rate of time preference: $p>0, Y$ is total output, $\mathrm{P}$ is aggregate stocks of private and public capital respectively, His the flow of non-capital public expenditure, $F$ is the stock of FDI, A is total factor productivity level a function of FDI the assumed that government runs a balanced budget by an output tax on firms. There is usually a problem of simultaneity biased when the error term is correlated with one or more of the explanatory variables. Simultaneity equally occurs when empirically evaluating FDI and economic growth. Having these in mind, our simultaneous equation model can be presented as follows:

$$
\mathrm{Yt} \quad=\mathrm{A}_{0} \mathrm{D}_{0}+\sum_{\mathrm{J}=1}^{\mathrm{K}} \underset{\mathrm{j}=1}{\mathrm{~K} \mathrm{y}_{\mathrm{t}-1}+\sum \beta \mathrm{jx}_{\mathrm{t}-1}+\sum_{\mathrm{t}}}
$$




$$
\mathrm{Xt} \quad=\mathrm{A}_{0} \mathrm{D}_{0}+\sum_{\mathrm{J}=1}^{\mathrm{K}} \underset{\mathrm{J}=1}{\mathrm{~K} \mathrm{x}_{\mathrm{t}-\mathrm{j}}+\sum \beta \mathrm{jy}_{\mathrm{t}-\mathrm{j}}+\mathrm{U}_{\mathrm{t}}}
$$

Where $\mathrm{D}_{0}$ is the deterministic (non-stochastic) variables is $\mathrm{A}_{0} \alpha \mathrm{jBj}$ is the parameter estimates, $\sum_{\mathrm{t}}$ and $\mathrm{U}_{\mathrm{t}}$ are the error terms respectively based on the above model. The variables in the model include $\mathrm{RGDP}_{\mathrm{t}}, \mathrm{FDI}_{\mathrm{t}}, \mathrm{PEX}_{\mathrm{t}}$, $\mathrm{XDB}_{\mathrm{t}}, \mathrm{M2}_{\mathrm{t}}, \mathrm{GCF}_{\mathrm{t}}, \mathrm{RGDP}_{\mathrm{t}-1}, \mathrm{EXR}_{\mathrm{t}}, \mathrm{INTR}_{\mathrm{t}}, \mathrm{INFR}_{\mathrm{t}}, \mathrm{INVYR}_{\mathrm{t}}$ and $\mathrm{FDI}_{\mathrm{t}}$ where $\mathrm{RGDP}_{\mathrm{t}}$ is real gross domestic product (as a proxy for economic growth), $\mathrm{FDI}_{\mathrm{t}}$ is foreign direct investment, $\mathrm{PEX}_{\mathrm{t}}$ is total public expenditure (capital and recurrent), $\mathrm{XDB}_{\mathrm{t}}$ is external debt burden, $\mathrm{M} 2_{\mathrm{t}}$ is broad money supply, $\mathrm{GCF}_{\mathrm{t}}$ is gross capital formation, $\mathrm{EXR}_{\mathrm{t}}$ is exchange rate, INTR $\mathrm{IN}_{\mathrm{t}}$ is interest rate (prime lending rate), $\mathrm{INFR}_{\mathrm{t}}$ is infrastructure development (captured by power generation), INVYR $\mathrm{I}_{\mathrm{t}}$ is investment-income ratio, $\mathrm{RGDP}_{\mathrm{t}-1}$ is one-year lag of RGDP, $\mathrm{FDI}_{\mathrm{t}-1}$ is one year lag of FDI.

Table I: Determinants of Economic Growth and FDI

\begin{tabular}{|c|c|}
\hline Explanatory Variables & Theoretical Signs \\
\hline Total public expenditure $\left(\mathrm{PEX}_{\mathrm{t}}\right)$ & + \\
\hline External debt burden $\left(\mathrm{XDB}_{\mathrm{t}}\right)$ & + \\
\hline Broad money supply $\left(\mathrm{M} 2_{\mathrm{t}}\right)$ & + \\
\hline Gross capital formation $\left(\mathrm{GCF}_{\mathrm{t}}\right)$ & + \\
\hline Exchange rate $\left(\mathrm{EXR}_{\mathrm{t}}\right)$ & + \\
\hline Lending interest rate $\left(\mathrm{INTR}_{\mathrm{t}}\right)$ & + \\
\hline Infrastructure development $\left(\mathrm{INFR}_{\mathrm{t}}\right)$ & + \\
\hline $\begin{array}{c}\text { Investment-income rate }\left(\mathrm{INVYR}_{\mathrm{t}}\right) \\
\left(\mathrm{RGDP}_{\mathrm{t}-1}\right)\end{array}$ & + \\
\hline $\begin{array}{c}\text { One-year lag of real gross domestic product } \\
\left(\text { FDI }_{\mathrm{t}-1}\right)\end{array}$ & + \\
\hline \begin{tabular}{c} 
One-year lag of foreinvestment \\
\hline
\end{tabular} & + \\
\hline
\end{tabular}

\section{Data}

The study uses a time series sample from 1980 to 2012. The data were sourced from various issues of the Central Bank of Nigeria Statistical Bulletin.

\section{EMPIRICAL RESULTS}

In this section, we shall examine and text for ducting unit root test for stationary. The order of such a series the determine the number of time it 
must be differenced to make it stationary following Engle and Granger (197) a non-stationary series is said to be integrated of order of if it can be stationary by differencing it and times; expressed as $\tilde{X_{t}} /(d)$. We employ the standard Dickey-Fuller (DF) test on each variable. The ADF test we done with the following hypothesis

- Null hypothesis $\left(\mathrm{H}_{0}\right)$ : Variable contains unit root and hence is nonstationary

- Alternative hypothesis $\left(\mathrm{H}_{1}\right)$ : Variable does not contain unit root hence stationary.

The result of the augmented Dickey-Fuller Test for unit root is presented as follows:

Table II: Unit Root Test for variables with Intercept and without Trend

\begin{tabular}{|c|c|c|c|}
\hline Variable & ADF Test Statistics & 9S5\% critical value & Order of integration \\
\hline $\mathrm{RGDP}_{\mathrm{t}}$ & $5.4329^{*}$ & -2.8861 & $1(1)$ \\
\hline $\mathrm{FDI}_{\mathrm{t}}$ & $-4.5632^{*}$ & -2.8859 & $1(1)$ \\
\hline $\mathrm{PEX}_{\mathrm{t}}$ & $3.2468^{*}$ & -2.8859 & $1(1)$ \\
\hline $\mathrm{XDB}_{\mathrm{t}}$ & $-2.4023^{*}$ & -2.8863 & $1(1)$ \\
\hline $\mathrm{M}_{\mathrm{t}}$ & $4.2250^{*}$ & -2.8863 & $1(1)$ \\
\hline $\mathrm{GCF}_{\mathrm{t}}$ & $4.4048^{*}$ & -2.8863 & $1(1)$ \\
\hline $\mathrm{EXR}_{\mathrm{t}}$ & 8.2478 & -2.8863 & $1(1)$ \\
\hline $\mathrm{INFR}_{\mathrm{t}}$ & $3.2880^{*}$ & -2.8863 & $1(1)$ \\
\hline $\mathrm{INVYR}_{\mathrm{t}}$ & $4.3982^{*}$ & -2.8863 & $1(1)$ \\
\hline $\mathrm{INTR}_{\mathrm{t}}$ & 2.4000 & -2.8863 & $1(1)$ \\
\hline $\mathrm{FDI}_{\mathrm{t}-1}$ & $4.4654^{*}$ & -2.8863 & \\
\hline $\mathrm{RGDP}_{\mathrm{t}-1}$ & $4.6584^{*}$ & -2.8863 & \\
\hline Note: $*$ indicates significance @ one percent
\end{tabular}

The above table indicates the result of the Augmented Dickey-Fuller (ADF). All the variables were stationary at first difference except RGDP, EXR, INTR and RGDP $\mathrm{t}_{-1}$. Exchange rate $\left(\mathrm{EXR}_{\mathrm{t}}\right)$ and interest rate were not stationary even after second difference. RGDP and $\mathrm{RGDP}_{\mathrm{t}-1}$ were stationary after second difference. It therefore shows that all the explanatory variables have long run relationships with the dependent variables except EXR and INTR. The ADF is to determine the time series properties of the data so as to ascertain the existence or otherwise of the integrated components among the variables. 
Table III: Two-Stage Least Squares (2SLS) Estimates of RGDP and FDI

\begin{tabular}{|c|c|c|}
\hline \multirow[t]{2}{*}{ Variables } & \multicolumn{2}{|c|}{ Equations } \\
\hline & RGDP & FDI \\
\hline $\mathrm{C}$ & $\begin{array}{c}37343.3 \\
(3.7225)^{* *}\end{array}$ & -65198.0 \\
\hline LFDI & $\begin{array}{c}-0.21893 \\
(-2.5756)^{* *}\end{array}$ & \\
\hline LPEX & $\begin{array}{l}0.03897 \\
(1.2236)\end{array}$ & \\
\hline LXDB & $\begin{array}{c}0.56479 \\
(2.8865)^{* *}\end{array}$ & \\
\hline LM2 & $\begin{array}{c}0.69730 \\
(1.7761)^{* *}\end{array}$ & \\
\hline LGCF & $\begin{array}{c}0.13997 \\
(2.3128)^{* *}\end{array}$ & \\
\hline LRGDP $_{\mathrm{t}-1}$ & $\begin{array}{c}0.10830 \\
(0.56657)\end{array}$ & \\
\hline LRGDP & & $\begin{array}{c}1.6262 \\
(3.5857)^{* *}\end{array}$ \\
\hline LEXR & & $\begin{array}{c}0.8255 \\
(1.8547)^{* * *}\end{array}$ \\
\hline LINTR & & $\begin{array}{c}1.64485 \\
(0.50737)\end{array}$ \\
\hline INFR $_{t}$ & $\begin{array}{c}-1.6256 \\
(-2.8756)\end{array}$ & $\begin{array}{c}2.2466 \\
(1.8829)^{* * *}\end{array}$ \\
\hline LINVYR & & $\begin{array}{c}-11.4049 \\
(-0.0082188)\end{array}$ \\
\hline $\mathrm{LFDI}_{\mathrm{t}-1}$ & & $\begin{array}{c}-2.2429 \\
(-2.3332)^{* *}\end{array}$ \\
\hline \multicolumn{3}{|c|}{ Summary Statistics } \\
\hline R-Squared & 0.87338 & \\
\hline R-Bar-Squared & 0.86666 & \\
\hline GR-Squared & 0.97411 & \\
\hline GR-Bar-Squared & 0.97273 & \\
\hline F-Stat. & 129.9070 & 9.1925 \\
\hline D.W-Stat & 1.9498 & 1.8298 \\
\hline $\begin{array}{cr}\text { Note: } t-v a l u e & \text { are } \\
* * & \text { Signif } \\
* * * & \text { Signif } \\
& \end{array}$ & $\begin{array}{l}\text { s below eac } \\
\text { nt level } \\
\text { ent level } \\
\end{array}$ & \\
\hline
\end{tabular}

Source: Authors' Computation

From the first equation, six explanatory variables were applied. The tvalue are all reported in parenthesis below each coefficient. The results comply with the aprior expectation except FDI. Considering the $\mathrm{R}^{2}$ of 0.87338 which is a measure of the coefficient of determination, it reveals that over 87 percent of the systematic variation in Real Gross Domestic Product (RGDP) was explained by the explanatory variables. This was equally 
supported by the adjusted coefficient of determination (R-Bar-Squared) of 0.8666 .

From the t-statistic, broad money supply (M2) was significant at 10 percent while other variables were significant at 5 percent except total public expenditure (PEX) and the lag value of RGDP that were not significant at all. The F-statistics of $F(6,113)$ is 129.9070 shows that all the variable put together were statistically significant at 5 percent level, indicating that there is a significant linear relationship between dependent and the explanatory variables. The Durbin Watson statistic of 1.8 shows that approximately, the absence of serial correlation. Generally, the model shows more predictive power, it can be relied upon for policy formulation. From the second equation, six explanatory variables were utilized. The t-values are reported in parenthesis below each coefficient. In over result, all the variables complied with the aprior expectation except INER and the ratio of investment to income (INVRY). The main reason the negative of infrastructural development (INFR) is due to the undeveloped nature of the Nigerian critical infrastructure, especially power generation that was used as a proxy in this research.

There is overall weak performance of the variables applied in the mode, since $\mathrm{R}^{2}$ and $\mathrm{R}^{2}$ feel below the $50 \%$. By implication over 60 percent of the systematic variation in FDI cannot be explained by the independent variables. Therefore the predictive ability of the model has been lost. From the t-ratios, the only significant variables are RGDP and INFR. These variables are statistically significant at the 5 percent level. The model also revealed the absence of serial correlation between explanatory variables and the dependent variables. This is indicated by the D.W-Statistic of 1.949.

\section{The Steady-State Elasticity Multiplier}

This is also called the long run coefficients. This can be obtained by ensuring that the value of the endogenous variables be stationary. From the result above, we can solve as follows:

Letting $\mathrm{LRGDP}_{\mathrm{t}}=\mathrm{LRGDP}_{\mathrm{t}-1}$ and $\mathrm{LFDI}_{\mathrm{t}}=\mathrm{LFDI}_{\mathrm{t}-1}$

The following results were obtained:

Table IV: Elasticity-Multiplier Coefficient

\begin{tabular}{|c|c|c|c|c|c|c|}
\hline Variable & PEX & EXR & XDBT & GCF & INFR & INTR \\
\hline RGDP & 0.217 & 0.792 & 0.456 & 0.819 & 0.920 & 0.761 \\
\hline FDI & 0.215 & 0.531 & 0.796 & 0.772 & 0.511 & 0.817 \\
\hline
\end{tabular}

Since the variables are in logarithms form, the coefficients are elasticities. But these elasticities only measure direct effects. This direct effect can be seen from table 3.3. The steady-state elasticity multiplier coefficients of these variables have been calculated and are reported in table 3.4 In view of the table above, a 10 percent increase in PEX will result in 2.1 
percent increase in RGDP and 2.15 increase in FDI. Also a 10 percent increase in EXR will result in 7.9 percent increase in RGDP and 5.3 percent increase in FDI. An increase in XDBT by 10 percent will increase RGDP and FDI by 4.5 percent and 7.9 percent respectively. An increase in GCF by 10 percent will increase RGDP and FDI by 8.1 percent and 7.7 percent respectively. When we increase INFR by 10 percent, there will be corresponding increase in RGDP and FDI by 9.2 percent and 5.1 percent respectively.

\section{Policy Implications:}

According to Galer and Moav (2004), the fundamental engine of economic growth varies at different stages of a country's development. While physical capital accumulation is germane to economic growth at the early stages of development, human capital accumulation. As such, one should expect that FDI public expenditure should stimulate economic growth. From our analysis, it is obvious that FDI acts as a catalyst to economic growth while public expenditure (PEX) has a negative and insignificant link to economic growth. It was also observed that gross capital formation (GCF) equally acts as a stimulant to economic growth. Therefore emphasis must be placed on FDI and GCF as policy variables by the relevant authority with a view of increasing the rate of economic growth in Nigeria.

\section{CONCLUSION}

Using quarterly time-series data in Nigeria, we examine the simultaneous relationship between FDI, public expenditure growth and economic performance in Nigeria. The results of this paper suggest some implications in building a theoretical model which structures the impacts of FDI on economic growth and the impact of economic growth on FDI. From our findings, in stimulating economic growth, the Nigerian government should intensify efforts in attracting foreign direct investment inflows.

\section{References:}

Aschauer, D.A. (1989). “Is Public Expenditure Productive?” Journal of Monetary Economics 23, 177-200.

Balasubramanyam, V.N., M. Salisu, and D. Sapsford, (1996). "FDI and Growth in EP and IS countries, "The Economic Journal 106, 92-105.

Barro, R.J. (1990), "Government spending in a Simple Model of Endogenous Growth,” Journal of Political Economy 98, S103-S125.

Barro, R., and X-I-Martin, (1992), "Public Finance in Models of Economic Growth” Review of Economic Studies 59, 645-661.

Blomstrom, M. (1992), "Host Countries Benefits of Foreign Investment," NBER Working Paper No. w3615. 
Borensztein, E., J.D. Gregorio, and J.W. Lee. (1998). “How Does FDI Affect Economic Growth?” Journal of International Economics 45, 115-135.

Devarajan, S., V. Swaroop, and H. Zou. (1996). "The Composition of Public Expenditure and Economic Growth,” Journal of Monetary Economics 37, 313-344.

Davarajan, S. and S. Vinaya (1993), "What do Governments Buy? The composition of Public Spending and Economic Performance”, Policy Research Working Paper, The World Bank, WPS 1082.

Diamond, J. (1989), “Government Expenditure and Economic Growth: An Empirical Investigation” IMF working Paper No. 8945, Washington D.C.

Durham, J.B. (2004), "Absorptive Capacity and the Effects of FDI and Equity foreign portfolio investment on economic growth," European Economic Review 48, 285-306.

Easterly, W., and S. Rebelo. (1993). "Fiscal Policy and Economic Growth: An Empirical Investigation,” Journal of Monetary Economics 32, 417-458.

Engle, R.F. AND C.W.J. Grenger (1987), “Cointegration and error correction: representation, estimation and testing”, Econometrica, 55, 251276.

Folster, S., and M. Henrekson, (2001). "Growth effects of government expenditure and taxation in rich countries,” European Economic Review 45, 1501-1520.

Folster, S. and M. Henrekson (1999), "Growth and the public sector: a critique of the critics”, European Journal of Political Economy, 15:2, 337358.

Galor, O., and O. Moav, (2004). "From Physical to Human Capital Accumulation: Inequality and the Process of Development," Review of Economic Studies 71, 1001-1026.

Girma, S. (2003), “Absorptiive Capacity and Productivity Spillovers from FDI: a threshold regression analysis, "European Economic Group, Working Paper 25/2003.

Granger, C.W.J (1990), “Introduction” in Granger, C.W.J (ed) Modelling Economic Series: Advanced Texts in Econometrics, Oxford University Press.

Grossman, P.J. (1983), "Government and Economic Growth. A non-linear Relationship”, Public Choice, Vol. 56, 193-200.

Gupta, S., B. Clements, E. Baldacci, and C. Mulas-Granados. (2002). "Expenditure Composition, Fiscal Adjustment, and Growth in Low-income Countries,” IMF Working Paper No. 02/77.

Hsieh, E. and Lai, K.S. (1994), "Government Spending and Economic Growth: The G-7 Experience”, Applied Economics Vol. 26, ISS 51, pp. 535542. 
Kormendi, R. and Meguire, P. (1985), Macroeconomic Determinants of Growth: Cross country evidence, Journal of Monetary Economics, 16, 141164.

Kneller, R., M. Bleaney and N. Gemmel (1998), "Growth, Public Policy and the Government Budget Constraint: Evidence from OECD Countries", Discussion Papers in Economics, DP 98/14, University of Nottingham.

Landau, D. (1983), "Government Expenditure and Economic Growth: Across-Country Study”, Southern Economic Journal 49, (3) pp. 783-92 January.

Landau, D. (1986), "Government and Economic Growth in the Less Developed Countries: An Empirical Study for 1960-1980”, Economic Development and Cultural Change, 35, 35-75. 